Amanda R. Greene*

\title{
Legitimacy without Liberalism: A Defense of Max Weber's Standard of Political Legitimacy
}

https://doi.org/10.1515/auk-2017-0017

\begin{abstract}
In this paper I defend Max Weber's concept of political legitimacy as a standard for the moral evaluation of states. On this view, a state is legitimate when its subjects regard it as having a valid claim to exercise power and authority. Weber's analysis of legitimacy is often assumed to be merely descriptive, but I argue that Weberian legitimacy has moral significance because it indicates that political stability has been secured on the basis of civic alignment. Stability on this basis enables all the goods of peaceful cooperation with minimal state violence and intimidation, thereby guarding against alienation and tyranny. Furthermore, I argue, since Weberian legitimacy is empirically measurable in terms that avoid controversial value judgments, its adoption would bridge a longstanding divide between philosophers and social scientists.
\end{abstract}

\section{Introduction}

All states seek to be legitimate. But identifying a standard for the political legitimacy of states is notoriously difficult, and past attempts at a philosophical definition of legitimacy have faced a number of challenges. Views that base legitimacy on the protection of rights are charged with making imperialistic value judgments, due to their ahistorical reliance on liberal democratic values. Views that base legitimacy on individual welfare are charged with an overly narrow view of the aims of politics. Meanwhile, there is a growing chasm between philosophers who theorize about what legitimacy is and social scientists who study and measure it. Leading social scientists point out that legitimacy has been under-theorized relative to the abundance of potential indicators (Gilley 2006a; Tyler/Jackson 2013). Since it is plausible to think that some states are more legitimate than others, it would be good to have a concept that permits measurement. Nevertheless, philosophers

*Corresponding author: Amanda R. Greene, University College London, e-mail:

a.greene@ucl.ac.uk 
have been reluctant to provide a definitional basis for comparisons across time and across countries. ${ }^{1}$

These issues can be partly explained by a methodological schism, growing out of two distinct approaches to legitimacy in the $20^{\text {th }}$ century. One approach, represented by Max Weber, sought to explain patterns of obedience in terms of beliefs about legitimacy (Weber 1978). Another approach, represented by Rawls and Habermas, sought to develop a normative justification of the liberal democratic state, based on an ethos of citizenship in conditions of disagreement (Rawls 2001; Habermas 1996). What the approaches have in common is an object of study: the forms of social organization that rely on structures of power and authority for their maintenance. But the former seeks to explain these forms, while the latter seeks to justify them, and their use of the term 'legitimacy' diverges accordingly. These days the former is often called sociological, descriptive, or perceived legitimacy; the latter is often called normative or liberal democratic legitimacy.

The two approaches have diverged over the last half-century to the point that they inhabit different disciplinary spheres. Each side maintains the disciplinary boundaries by translating the other side's insights into their own terms. Social scientists, on the one hand, tend to incorporate the analysis of norms into their broader descriptive enterprise (Tyler 2006a; Gilley 2009). For instance David Beetham, the most prominent political scientist writing on legitimacy, says, "I am concerned with legitimacy as a problem for social science rather than for philosophy [...] [because] the two activities have a different purpose and a different logic.” (Beetham 1991b, 7) Philosophers for their part often insist that the normative use of the idea of legitimacy must be carefully distinguished from the descriptive idea, because the descriptive facts about what people happen to believe about their government lack direct significance for legitimacy. ${ }^{2}$ Philosophers tend to fold the descriptive enterprise into the normative one, focusing on liberal democratic legitimacy in the Rawlsian mold (Estlund 2007; Peter 2009). From time to time, the sociological concerns break into the normative discussion via

1 For a discussion of the difficulty of defining political legitimacy, see section 1 of Peter 2016. There are discussions related to political legitimacy in the literatures on political obligation (Simmons 2000; Gilbert 2006; Klosko 2005) and legitimate authority (Raz 1986; 2006; Green 1990), but they do not take political legitimacy as the primary unit of analysis. Recently there has been an uptick in discussions of legitimacy as such, though without specific attention to measurement, e.g. Tasioulas 2010; Pettit 2012; Buchanan 2013.

2 For endorsements of the strict distinction between normative and perceived legitimacy, see among others Buchanan/Keohane 2006; Copp 1999; Rawls 2001; Shaw 2008; Peter 2009. 
debates about feasibility and non-ideal theory (Simmons 2010; Estlund 2014), but for the most part they go their separate ways. ${ }^{3}$

In this paper, I take the first step towards bringing these two approaches to legitimacy back together. ${ }^{4}$ I do this by offering an elaboration of the Weberian account of political legitimacy as the degree to which a political order is regarded by its subjects as having a valid claim to rule. Then I show how current research in the social sciences reflects this definition, allowing them to discover connections between legitimacy and important social goods. In light of these findings, I argue that the attainment of Weberian legitimacy has moral significance because it achieves political stability on the basis of civic alignment. Furthermore, I argue that it avoids shortcomings of other normative standards of legitimacy due to its amenability to measurement and avoidance of controversial value judgments. Therefore, its adoption would allow for a more universalistic basis for the moral evaluation of states, while helping to close the gap between philosophers and social scientists.

\section{A Weberian Account of Legitimate Rule}

Philosophers tend to think of Max Weber primarily as a social theorist who proposed a threefold typology of legitimacy on the basis of charisma, tradition, and legal rules. While awareness of these three is commonplace (Derman 2013), there is far less understanding of what these three categories are types of -that is, why Weber thought these were instances of one and the same human phenomenon. Although Weber's answer to this question is implicit, it constitutes an original philosophical account of human sociality, in my view. As Sheldon Wolin has powerfully argued, Weber's acts of "naming" recast social science as the "politics of the soul" (Wolin 1981, 406-410). In what follows, I present a philosophical elaboration of Weber's account of legitimacy.

Answering this question-what are the three types of legitimate rule types of?-must begin with Weber's analysis of Herrschaft in Economy and Society. The prominent Weber translator Talcott Parsons notes that "the term Herrschaft has no satisfactory English equivalent [...] [though] the term 'imperative control' is close

3 One notable exception in the last decade is the revival of political realism (Williams 2005; Geuss 2008; Rossi/Sleat 2014). For an analysis of the limitations of a realist theory of political legitimacy, see Greene 2017.

4 While I am sensitive to the possibility that there is no univocal sense of the term 'legitimate', I think it is a question worth investigating. 
to Weber's meaning” (Weber 1978, 61). Variously translated as 'imperative coordination', ‘domination', 'mastery', or 'authority', I will translate it as 'rule' because I think that term best fits the range of contexts in which it is used (Wolin 1981, 407; Shaw 2008, 34). According to Weber, rule can be found whenever there is "the actual presence of one person successfully issuing orders to others", where success corresponds to "the probability that a command with a given specific content will be obeyed by a given group of persons" (Weber 1978, 53). Weber distinguishes rule from power (Macht), which he defines as "the probability that one actor within a social relationship will be in a position to carry out his own will despite resistance, regardless of the basis on which this probability rests" (53; 212). Weber adds that rule normally sustains itself through an administrative staff or organization, which he defines in broad terms: "A ruling organization (Herrschaftsverband) exists insofar as its members are subject to rule by virtue of the established order." (53) Thus for Weber, the defining characteristic of rule is generalized obedience to a system of order.

\subsection{Weber on Legitimacy}

Weber distinguishes legitimate rule from illegitimate rule in terms of the mode of obedience. He contrasts a willingness to submit that is based on fear or on immediate advantage with one that is based on beliefs about the rightfulness of the authority. As Parsons explains, "[s]o far as it is not derived merely from fear or from motives of expediency, a willingness to submit to an order imposed by one man or a small group, always implies a belief in the legitimate authority" (Weber 1978, 37). For Weber, what makes the difference is not so much the psychological cause as whether the command is treated as a maxim of action by those who are obeying. He explains:

"[Legitimate] rule will thus mean the situation in which the manifested will (command) of the ruler or rulers is meant to influence the conduct of one or more others (the ruled) and actually does influence it in such a way that their conduct to a socially relevant degree occurs as if the ruled had made the content of the command the maxim of their conduct for its very own sake. Looked upon from the other end, this situation will be called obedience." (Weber $1978,946)^{5}$

5 Weber is speaking of legitimate rule rather than mere rule because he says, "[i]n the following discussion we shall use the term rule exclusively in that narrower sense which excludes from its scope those situations in which power has its source in a formally free interplay of interested parties [...] rule shall be identical with authoritarian power of command" (946). 
In other words, the obedience occurs because the subject treats the command as a maxim of action. How is this different from a threat, request, or piece of advice? Later in the same passage, Weber says, "[t]he merely external fact of the order being obeyed is not sufficient to signify rule in our sense; we cannot overlook the meaning of the fact that the command is accepted as a 'valid' norm." (946) So Weber explicitly points to the idea that commands are accepted by subjects, where this means they are regarded as valid commands in some sense. As Peter Lassman says, "[t]he concept of legitimacy refers to the acceptance of the validity of an order of rules" (Lassman 2000, 87). It seems that accepting a command as valid involves taking the fact that $\mathrm{X}$ is commanded as a reason to $\mathrm{X}$. Hence there is an affinity with the standard concept of law, as it has been expounded since at least Hobbes: "Law is a command of that person (whether man or council) whose instruction is the reason for obedience." (Hobbes 1998, 154)

Still, it is not very clear what this 'acceptance of validity' amounts to. It will help to look at Weber's suggestion that legitimate rule must engage in selfjustification. He says in Part II of Economy and Society, "the continued exercise of every domination [rule][...] always has the strongest need of self-justification through appealing to the ultimate principles of its legitimation" (Weber 1978, 954). Weber has already presented the principles of legitimation in Part I as falling into three 'pure types':

"The validity of the claims to legitimacy may be based on:

1. Rational grounds-resting on a belief in the legality of enacted rules and the right of those elevated to authority under such rules to issue commands (legal authority).

2. Traditional grounds-resting on an established belief in the sanctity of immemorial traditions and the legitimacy of those exercising authority under them (traditional authority).

3. Charismatic grounds-resting on devotion to the exceptional sanctity, heroism or exemplary character of an individual person, and of the normative patterns or order revealed or ordained by him (charismatic authority)." (Weber 1978, 215).

These three types of legitimate rule are pure only in theory; in reality they are always blended (37). The point of separating them, then, is to show how the basis for obedience rests on the perceived validity of the type of rule that is being claimed and exercised-i.e. "belief in [that type of] legitimacy" (215). In other words, the three types are three modes of justifying rule in terms of what a ruling organization might appeal to as the basis of its legitimacy.

Weber's presentation of three pure types in theory is not as innocent as it might seem (Wolin, 406). For while Weber doesn't think they are mutually exclusive, he still presents the three as collectively exhaustive without much justification (Weber 1978, 213). Why does Weber carve up the universe of legitimate rule 
this way? That is to say, why does he identify all and only these three ${ }^{6}$ For example, Weber does not mention democratic grounds as a type of self-justification, even though he has much to say elsewhere about how it attains legitimacy (Kalyvas 2008; Klein 2017). What do the three types have in common with each other, that they don't have in common with obedience that is secured by the operation of fear or immediate advantage? To pose the question as I did earlier, what are these three instances of? It appears that they are held to be distinct as modes of self-justification, implying that a ruling organization makes essential reference to itself, in some sense.

The implication, in my view, is that a ruling organization presents itself as being justified in terms of something that it partly embodies, but also something that points beyond itself. For example, a ruling organization that operates according to legal rules could not engage in charismatic self-justification, because rule is not being exercised by a charismatic leader; and vice versa. These are ruled out because the principle of legitimation would not fit the facts about how authority is systematically exercised. The self-justification that Weber identifies, then, is irreducibly self-referential because each ruling organization makes reference to its particular mode of exercising authority. This is why Weber calls the subjects' attitudes 'belief in legitimacy', where the term 'legitimacy' is a kind of placeholder, leaving open the different principles of legitimation that a ruling organization might appeal to. Weber thinks these three types exhaust the ways in which a ruling organization might can achieve 'self-justification through appealing to the principles of its legitimation'. Thus, the idea of self-justification is what explains why Weber carves up the universe of legitimate rule into only three types-again, not mutually exclusive, but nevertheless, collectively exhaustive. I will have more to say about this later.

\subsection{What Is Political Rule?}

Weber famously defines a political organization as one that upholds its order through the "threat and application of physical force" within a given territory (Weber 1978, 54). However, at the end of Part Two of Economy and Society, Weber expands on the nature of a political community:

\footnotetext{
6 Though Weber most often presents the typology as threefold, it is not always the case. In Part I, he lists four grounds: traditional, affectual, value-rational, and legal (Weber 1978, 36). Still, in his last statement of Economy and Society, he says "of such ultimate principles, there are only three [expressions of] the 'validity’ of rule” (Weber 1978, 954). See also Beetham 1991a.
} 


\begin{abstract}
"As a separate structure, a political community can be said to exist only if, and in so far as, a community constitutes more than an 'economic group'; or, in other words, in so far as it possesses value systems ordering matters other than the directly economic disposition of goods and services. [...] In our terminology, a separate 'political' community is constituted where we find (1) a 'territory'; (2) the availability of physical force for its domination; and (3) social action which is not restricted exclusively to the satisfaction of common economic needs in the frame of a communal economy, but regulates more generally the interrelations of the inhabitants of the territory." (Weber 1978, 902) ${ }^{7}$
\end{abstract}

Thus a political community involves something more than a monopoly on force. The community is said to 'possess' value systems, and the resultant ordering of interaction goes beyond economic exchange. This can be understood, roughly, as the regulation of human behaviour such that it is ordered towards some end, and this end is seen as valuable. Here Weber seems to echo Aristotle when he defines a political community in the Politics. In Book III, Aristotle indicates that a political community is to be defined as a partnership for the sake of ends that go beyond mutually useful cooperation, e.g. defense and trade. According to Aristotle, a partnership for these ends requires the establishment of common rulers (1280a31-1281a9) (Aristotle 1984). Whereas for Aristotle the end is a partnership for the sake of human excellence, for Weber the end is left unspecified. Still, it is important to notice that while no particular end or value system is specified as definitive of a political community, nevertheless it is part of the definition that there is an ordered orientation to some value system. ${ }^{8}$

When a political community has a ruling organization, it faces a greater need for legitimacy than other types of ruling organizations (Lassman 2000, 88-90). The evident convergence of interests that might provide stable underpinning in other forms of rule is lacking, so self-interest is less sustainable as a basis for willing submission. Moreover, the ruling organization cannot rely entirely on violence to secure obedience, though it needs to have credible recourse to violence. Because the requirement of obedience is unbounded and individuals can't easily see how their interests are served, normally political rule will not be able to perpetuate itself unless it secures legitimacy.

7 I thank Ilaria Cozzaglio for extended and illuminating conversations about this passage.

8 This comment of Parsons' is misleading: "It is not possible to define a political organization, including the state, in terms of the end to which its action is devoted [...] [but] only in terms of the means peculiar to it, the use of force." (Weber 1978, 55) The emphasis on distinctive means is correct, but the denial of ends is too simple. All that is ruled out is that any particular end can be definitive of a political organization. 
How does a ruling organization in a political community secure legitimacy through self-justification? ${ }^{9}$ Self-justification presupposes the three features of a political community: a defined territory, a monopoly on force, and a value system. Therefore, any belief in the validity of rule will include, accordingly, three more specific beliefs: that the power has supreme authority within a territory, that it is uniquely justified in using violence, and that its ordering of common affairs corresponds to a value system. One necessary task of those exercising political rule is to uphold the value system(s) that underpin a belief in the validity of rule, as well as the perception that power is being exercised accordingly. This leads them to seek self-justification through some combination of Weber's three types of legitimacy. ${ }^{10}$

\subsection{Assent to Rule}

According to this reading of Weber, a ruling organization secures legitimacy when its subjects accept the validity of its claim to rule. I will elaborate this idea by introducing two terms of art: an 'essential claim of rule' and 'assent to rule'. Recall that Weber identifies a political community as a social structure in which collective affairs are ordered according to a value system. Since a political community is a system of social regulation over a defined territory with an exclusive claim to use violence, then there is a sense in which all systems of political rule present themselves as having these features. Thus every political ruling organization makes a claim to rule in light of some value system, through a monopoly on violence within a particular territory. At a formal level, this claim demarcates a political order from other forms of human organization, including religious and economic ones. Therefore, I call this the essential claim of political rule: to exercise rule over a defined territory, with a monopoly on authorized force, in a way that corresponds to a value system that goes beyond individual interests. ${ }^{11}$

\footnotetext{
9 A political community need not, as a matter of definition, involve a political ruling organization such as the state. But at the very least it will involve a pattern of obedience (Weber 1978, 903). 10 Weber's account of legitimacy offers some modest grounds for criticizing those who exercise rule. Political actors are free to pursue a wide range of aims and employ a wide range of means, but they are subject to criticism whenever their ends or means undermines the value system on the basis of which power derives its justification. For further discussion, see Greene/Cozzaglio 2017.

11 Though I cannot pursue it here, this way of understanding legitimacy shares features with Joseph Raz's approach to explaining normative concepts. He says, "[t]here is a class of normative concepts that have a secondary use in which they indicate a claim by their users, or some of them,
} 
Assent to rule is the acceptance of rule by a subject, combined with a belief in the validity of the ruling organisation's claim to rule, i.e. the claim to have an exclusive right to use violence within a territory for the advancement of some values. The assessment by subjects of a ruling organization cannot at the same time contradict this claim of rule; otherwise the assessment would not quality as a belief in validity. A belief in the validity of rule implies a belief that the ruling organization is using its power and authority in service of aims that are, at a minimum, compatible with the very idea of a political community. In other words, one cannot judge a regime to be a valid political order unless one at the same time judges it to be a political order. Therefore, a subject cannot affirm a value system that is inconsistent with the essential claim of political rule.

What sorts of beliefs are excluded by this definition of assent to rule? Not much, as Weber means it to cover an immense range of historical forms of political community. Nevertheless, there are a few formal constraints. First, the subject must see the political order as being aimed at something beyond itself, because a system of political power exists for the sake of coordination according to some value system. That is, the value system in light of which the subject regards the rule as being valid cannot be the preservation of rulers' power for the sake of power. Thus it excludes the belief that the government rules only for its own sake, in order to advance the interests of the rulers against the ruled. Thus the assent to rule implies that subjects believe that their system is not a tyranny. Second, the subject must see the political order as aiming to protect subjects from unauthorized violence, because the political order claims the exclusive right to use violence. This disqualifies a subject who believes, for instance, 'the state practices illicit violence on its subjects', or 'the state allows some subjects to practice illicit violence on other subjects'. So a belief in validity rules out the approval of two forms of excessive: cruelty, because it is judged to be illicit violence, and tyranny, because it is judged to be violence aimed at augmenting the rulers' power. These two exclusions are ultimately derived from Weber's definition of a political community. Therefore, I use the essential claim of rule implicit in Weber's definition of a political community to identify what counts as assent to rule.

On this reading, Weber emerges as a unique theorist of the role of values in political subjection. Philosophers often frame the question of legitimacy in terms of solving a problem that arises between two parties that are imagined to be in a horizontal relationship of parity. For example, a social contract thinker like Locke argues that two individuals, who are taken to be free and equal by nature, are

that they apply in their primary, normative, sense, a claim that may be erroneous [...]" (Raz 2006, 1005-1006). 
likely to disagree on their natural entitlements, and so a judge must be set up in order to adjudicate the dispute between them (Locke 1980). Even contemporary legal philosophers begin with the horizontal dyad. The most prominent philosopher of legitimate authority, Joseph Raz, begins his analysis of what authorities do by considering a voluntary arbitration between two disputants, and he proceeds to argue that much of what is essential can be learned from that paradigmatic case. ${ }^{12}$ Weber, on the other hand, takes a vertical dyad to be fundamental: that is, a relationship between someone who is standing above, giving commands, and someone who is standing below, being commanded. Thus Weber's approach starts by accepting relations between two individuals who are not on a par, not presumed to be equals. Rather, the two parties are vertically related through a hierarchical structure of command and obedience. Weber takes this universal feature of human organization as a given, and it leads him to theorize about political legitimacy in a way that is very different from the social contract theorists. ${ }^{13}$

\section{Empirical Measurements of Weberian Legitimacy}

The Weberian understanding of legitimacy that I have sketched has been studied empirically by social scientists for the last 25 years. The research program can be traced almost entirely to one political theorist who began his career as a scholar of Weber, David Beetham (Beetham 1985; 1989). In his 1991 book The Legitimation of Power, Beetham developed and defended a framework for legitimacy that was subsequently applied to many different contexts (Beetham 1991b). In fact, Beetham's concept of legitimacy has been so seminal that it warranted the production of a second edition of the book, in which Beetham refines and extends el-

\footnotetext{
12 Raz's characteristically nuanced discussion admits that not all authority matches this paradigm, though he thinks that more does than we notice. At any rate, he takes the case of arbitration between two disputants to best illustrate the pivotal idea in his analysis of legitimate authority-namely, that authorities impose duties by creating pre-emptive reasons that purport to reflect the underlying reasons (Raz 1986, 41-44).

13 The only other modern political philosopher to take this approach is Hannah Arendt, who says, "The authoritarian relation between the one who commands and the one who obeys rests neither on common reason nor on the power of the one who commands; what they have in common is the hierarchy itself, whose rightness and legitimacy both recognize and where both have their predetermined stable place.” (Arendt 1993, 93)
} 
ements of his framework (Beetham 2013). In what follows I will explain Beetham's framework, as well as some of its applications and results.

\title{
3.1 Beetham on the Legitimation of Power
}

\section{David Beetham develops a threefold discursive framework for legitimate power:}

\begin{abstract}
"Power can be said to be legitimate to the extent that: (i) it conforms to established rules [governing the acquisition or exercise of power], (ii) the rules can be justified by reference to beliefs shared by both dominant and subordinate, and (iii) there is evidence of consent by the subordinate to the particular power relation.” (Beetham 2013, 15-16)
\end{abstract}

Beetham justifies his threefold definition by pointing out that each of the three elements-legality, normative justification, and consent-can independently contribute to or detract from the legitimacy of a state $(2013,16) .{ }^{14}$ In the revised edition, Beetham indicates that the second element is the 'core' component of legitimacy, while the legality and consent elements are secondary factors. ${ }^{15}$ The second element corresponds quite closely to Weber:

\begin{abstract}
"To be justified, power has to be derived from a valid source of authority [...] the structure of power must be seen to serve a recognizably general interest, rather than simply the interests of the powerful. These justifications in turn depend upon beliefs current in a given society about what is the rightful source of authority; about what qualities are appropriate to the exercise of power and how individuals come to posses them; and some conception of a common interest, reciprocal benefit, or societal need that the system of power satisfies." (Beetham 2013, 17)
\end{abstract}

Thus Beetham echoes Weber's emphasis on the nature of the beliefs that underlie obedience. They both think that a subject's beliefs about power allow for a kind of congruence between the value system of the subject and his regime. In the 2013 revised edition, Beetham also drops the terminology of consent, instead referring to the third element as performative endorsement: 'acts of recognition,

14 Beetham takes himself to have modified the 'received view' of Weber on the relationship between legitimacy and people's beliefs (1991a; 2013, 11-13). Beetham says, a "given power relationship is not legitimate because people believe in its legitimacy, but because it can be justified in terms of their beliefs" $(2013,11)$. I do not think Beetham needs to attribute to Weber the idea that legitimacy equals 'belief in legitimacy', though defending this depends on more exegesis of Weber than I can undertake here.

15 He says, "[m]ost of the research [...] concentrates attention on the component of legitimacy which I term 'normative justifiability'. This may indeed form the core of legitimacy, with legality serving as precondition and acts of recognition as a mode of reinforcement.” $(2013,293)$ 
acknowledgement, or engagement' that indicate an underlying acceptance to observers (2013, 266-67). Though Beetham's view has been refined over the years, it is ultimately a rendering of Weber into contemporary terms, enabling a whole generation of social scientists to study legitimacy.

\subsection{Tyler on Obeying Legal Authorities}

In his landmark 2006 book, Why People Obey the Law, psychologist Tom Tyler examines the connections between citizens' everyday attitudes towards legal authority, especially the police and courts, and their willingness to obey legal authority. Tyler's overarching concern is to understand how governments create and uphold social order through compliance with the law. He observes, "[t]he dominant approach to securing compliance has been through the threat or use of punishment-that is, via deterrence" (Tyler 2006b, 269). Against this, Tyler argues that the evidential basis for deterrence as a means of compliance is weak, and that it also has many negative consequences, such as mass incarceration, mistrust of the police, and marginalization of minorities. Thus Tyler's goal is "to articulate and defend empirically an alternative vision of social order maintenance linked to gaining the consent and cooperation of the public with the law and legal authorities" (270).

Tyler initially set out to assess legitimacy in terms of two factors that he measured through surveys: a felt sense of obligation to obey, and trust and confidence. In the context of police and courts, he found that the willingness to obey depends more on fair treatment than on judging that outcomes are correct or efficient (Sunshine/Tyler 2003; Tyler 2006b). This led Tyler to further investigate the link between obedience and perceptions of procedural justice (Levi/Sacks/Tyler 2009). Over time, he came to understand legitimacy in broadly Weberian terms, i.e. "a belief about the moral right of [authorities] to possess and exercise power and influence" (Tyler/Jackson 2013, 13). In his more recent work, Tyler calls for further analysis of the causes and constitutive factors of legitimacy, explicitly comparing his views with Beetham's original framework for legitimacy (9-13). ${ }^{16}$

Tyler's research shows an array of linkages between legitimacy and cooperation with public authorities (Tyler/Jackson 2013, 3). Overall, he argues that the value of legitimacy corresponds to securing social order, and thus public goods, with minimal threat or use of violence:

16 For a discussion of the difficulties in defining legitimacy in order to measure its effects, see Tyler 2006b, 19-39. 


\begin{abstract}
"The value of cultivating legitimacy lies in the fact that it enables the effective exercise of social authority. While authorities can exercise power directly through the promise of rewards or the threat of punishment, such approaches [...] may be especially problematic during instability or crisis, when authorities need the support of the people at a time in which they lack control over resources [...]. If a system enjoys widespread legitimacy, authorities can appeal to members based upon their shared purposes and values, providing the system with much-needed stability.“ (Tyler/Jackson 2013, 16)
\end{abstract}

In this way, Tyler's research confirms Weber's emphasis on shared values as the basis for social action. Tyler defines shared values as "those moral beliefs to which people appeal for the ultimate rationales of action” (11). For Tyler, the presence of shared values explains why compliance is better secured through legitimacy than through a rational calculation of self-interest. In fact, Tyler describes subjects' acceptance of the validity of authority as 'moral alignment'. He says, "[w] hen one believes that police officers act in accordance with an appropriate sense of right and wrong, this constitutes a conferred moral validity to their possession of power" (11). This alignment leads to an internalization of the command structure on the basis of values, which in turn produces social order through self-regulation (Tyler 2006b, 275; Tyler/Jackson 2013, 20). For example, one study (that invites follow up) found that, among young men in urban areas, legitimacy is inversely correlated with positive views of the appropriateness of using violence (Jackson et al. 2013). This idea of obeying the law through self-regulation corresponds closely to what Weber called regarding a command as a 'maxim of action for its own sake'. In Tyler's language, "people obey the law because they believe that it is proper to do so" (Tyler 2006b, 178). ${ }^{17}$

\title{
3.3 Gilley on Cross National Comparisons
}

The political scientist Bruce Gilley builds on Tyler and Beetham's work, extending it most notably to making cross-national comparisons of legitimacy. His 2009 book, The Right to Rule: How States Win and Lose Legitimacy, analyzes data from 72 different countries, representing 83 percent of the world's population. Gilley defines legitimacy as follows: "A state is more legitimate the more that it is treated by its citizens as rightfully holding and exercising political power." (Gilley 2006a, 500) Gilley uses Beetham's threefold framework in order to identify relevant data

17 Tyler says, "[t]he image of the person resulting from these findings is one of a person whose attitudes and behaviour are influenced to an important degree by social values about what is right and proper [...]. People are more responsive to normative judgments and appeals than is typically recognized.” (178) 
that can be effectively combined to form an index of legitimacy for each nation. Gilley rightly observes, "[c]ross-national statistics are insufficient for a fully specified model of legitimacy. Yet they are a necessary starting point for such discussions and have thus far been a weak point in the literature on the subject." (2006b, 48)

Gilley intends to operate with a fully theorized concept of legitimacy, pressing the idea further than anyone else to-date. Still, several challenges remain that are ripe for philosophical consideration. Gilley's project faces a typical problem in social science, which is how to measure latent concepts that lack direct indicators (such as GDP). In order to construct a model for purposes of measurement, a concept must be broken down into enough component elements in order to have a feasible strategy for isolating and gathering the relevant data. At the same time, the construction of a model must not be done in such a way that the corresponding breakdown and recombination introduces distortion. While difficult, it has been done successfully with other latent concepts like "cultural diversity" (Fearon 2003) and "poverty" (Alkire/Foster 2011). It is important to note that the moral significance of these ideas need not stand in the way of their effective measurement; in fact, empirical investigation and moral understanding often advance together, as in the case of development (Sen 1999; Alkire 2005).

In constructing the model of the concept, Gilley makes choices about which variables to include and how much relative weight to give them in the aggregation. First, he weights individual attitudes equally in the national aggregation, such that each person's assent to rule counts the same. He admits this lacks a satisfactory justification, other than that any other method of aggregation across persons is less justifiable (Gilley 2006a, 501). Second, he assigns twice as much weight to one of Beetham's three factors, the normative justifiability in terms of beliefs (510). While this is in accordance with Beetham's own acknowledgement of its relative centrality, it remains somewhat crude. ${ }^{18}$ Gilley makes a plea to philosophers for more theorization so that measurement can be better operationalized (this paper aims, in part, to respond). Still, Gilley remarks rightly that any lingering methodological disadvantages must be weighed against the advantage of having a metric at all (500).

The value of measuring legitimacy, even when the model is imperfect, depends on why legitimacy is something we care about. Gilley has plenty to say about the instrumental importance of legitimacy. For instance he says, "[s]tates that lack legitimacy devote more resources to maintaining their rule and less to

18 Gilley suggests that these choices led to an $18 \%$ improvement in the ability to measure the latent concept of legitimacy (517). 
effective governance, which reduces support and makes them vulnerable to overthrow or collapse" (499). But Gilley thinks that legitimacy is important not only for its consequences, and here his reflections invite philosophical engagement. He says,

"[m]ost individuals prefer to relate to the powerful in moral rather than in self-interested terms. Citizens strive to engage the state as moral agents, and a state that reciprocates will see its standing enhanced [...]. Whatever else legitimate states do for their citizens, one of the greatest public services they deliver is rightful rule itself. Political science is unique in having an entire branch of philosophy attached to it for this reason: achieving rightful rule is a momentous social feat. By implication, low-legitimacy states are failing to deliver an important public service, namely allowing citizens to esteem the rulers that claim their obedience." (Gilley, 2009, 141, emphasis added)

Though Gilley carefully avoids making outright moral pronouncements, he seems to suggest that legitimacy is morally valuable, for its own sake.

As far as I am aware, no philosopher has discussed these remarkable empirical findings. And yet, the Beetham-Tyler-Gilley research program continues to advance, with application to a growing variety of contexts. Gilley himself engages in in-depth studies of legitimacy in China and Uganda (Gilley 2008; 2009; 2012). Those who study emerging forms of political authority in conflict zones use legitimacy to explain the durability of de facto states (Bakke et al. 2014; 2017; Weigand 2017). Scholars of the European Union increasingly use legitimacy as a lens through which to understand the political dynamics of the region. In fact, EU scholars have generated a new threefold typology of legitimacy-input, output, and throughput legitimacy-which raises the question that confronted Weber of whether and why legitimacy consists of types (Scharpf 1999; Schmidt 2013). As social scientists continue to refine the concept of legitimacy in order to study it with more precision, they tend to emphasize that future research would benefit from a deeper theorization of the concept (Gilley 2006a; Levi/Sacks/Tyler 2009; Tyler/Jackson 2013).

\section{Moral Significance of Weberian Legitimacy}

So far I have argued that the Weberian concept of legitimacy that I elaborated as 'assent to rule' is empirically tractable and connected to important social goods. Now I will argue that Weberian legitimacy is morally valuable, though its value is conditional. I argue that it corresponds to 'stable civic alignment', which is the realization of political stability with minimal brutality and intimidation. The absence of civic alignment, I argue, results in instability, alienation and tyranny. 


\subsection{Political Stability}

Philosophers tend to downplay stability as an end in itself. For instance, Rawls conceives of stability as a matter of moral psychology that bears on justice indirectly, as a precondition rather than a constituent of justice (Rawls 1971, 336-37; 2001, 185-86). While it is true that stability is only conditionally valuable, it has an integral role to play in securing justice and the common welfare. For, a lack of stability introduces unpredictability and the threat of violence, which directly reduce wellbeing. Any element that contributes to political stability contributes, by implication, to all the goods of political association, including peace and justice.

At an individual level, stability relates to the value of being able to plan one's life-this requires predictability in the social, political, economic, and legal aspects of the normative landscape. No state can completely eliminate crime on the margins, but reducing it, and enabling subjects to protect themselves from it where it remains, enhances the exercise of agency by individuals and groups within society. Stability also allows for the promotion of general welfare and utility through economic exchange, since cooperative arrangements can be improved over time by optimizing within predictable circumstances. Finally, stability provides the foundation for most forms of human excellence that require sustained effort and practice within a community.

Weberian legitimacy provides a more reliable basis for stability, as shown in the last two decades of empirical research. The connection between legitimacy and stability is stressed by Beetham:

\footnotetext{
"Above all, [an understanding of legitimacy] helps explain the erosion of power relations, and those dramatic breaches of social and political order that occur as riots, revolts, and revolutions. It is not just because these events are particularly dramatic and fateful that they interest the social scientist. As with so much else about society, it is only when legitimacy is absent that we can fully appreciate its significance where it is present, and where it is so often taken for granted.” (Beetham 2013, 6)
}

Thus, Weberian legitimacy is tied to avoiding civil unrest and instability. Weber himself says that legitimacy produces the most stable rule, while "purely material interests and calculations of advantages [...] result [...] in a relatively unstable situation" (Weber 1978, 213).

Furthermore, Weberian legitimacy provides a qualitatively superior basis of stability because regularities of behavior are achieved with far less coercion and intimidation. In other words, Weberian legitimacy delivers more stability with less brutality. When Weberian legitimacy is present, intimidation and punishment are less important because subjects relate to norms of the system as valid commands (Tyler 2006b). For example, Weberian legitimacy makes policing of crime more 
communal, because citizens are more willing to cooperate with and aid the police. Tyler says, "[p]olice officers and judges who recognise and respond to people's normative concerns can exercise their authority more effectively; their rules and decisions will be accepted and obeyed voluntarily." (Tyler 2006b, 178) So at the individual level, compliance does not require the regime to provide ongoing motivation through fear or incentives, which often involve the police using violence and manipulation against the people they are meant to serve. Edmund Burke describes this as a society where authority is supported by a "mixed system of opinion and sentiment", a situation that has the result of making "power gentle and obedience liberal" (Burke, 67).

Beyond changing the character of criminal justice, there is also the factor of politically-motivated disobedience. Stability based on Weberian legitimacy reduces the likelihood of rebellion or terrorism, and thus the ongoing fear of them. Rebel and extremist groups find it easier to gain traction when there is a lack of system-level legitimacy. In a state with Weberian legitimacy, rebellion by groups seeking political upheaval will be viewed by the remaining citizens as threatening to the community. Since most citizens perceive the system as valid, they will perceive violent disobedience as unjustified. As they respond by bringing social pressure to bear on rebels through shame and exclusion, this reaction will reduce the need for subduing the rebellion through state violence. In liberal societies, social ostracization takes the place of violent repression, thereby preserving space for freedom of speech and association. Thus stability based on Weberian legitimacy can help to peacefully preserve the political and constitutional culture-hence Burke's comment that it makes 'power gentle and obedience liberal'. Whether or not this capacity always cuts in the direction of increasing justice, it at least avoids violence and political unrest, activities whose consequences are unpredictable. ${ }^{19}$

\subsection{Non-Alienation}

When stability is achieved by a state on the basis of Weberian legitimacy, it represents the attainment of something objectively valuable: the avoidance of alien-

19 Arendt famously argued that revolutionary violence presents unavoidable hazards. She says, "[...] the danger of the practice of violence, even if it moves consciously within a non-extremist framework of short-term goals, will always be that the means overwhelm the end. If goals are not achieved rapidly, the result will not merely be defeat but the introduction of the practice of violence into the whole body politic. Action is irreversible, and a return to the status quo in case of defeat is always unlikely. The practice of violence, like all action, changes the world, but the most probable change is a more violent world.” (Arendt 1969) 
ation from one's own political order. This alienation is objectively bad, for the individual and for the community. Consider the rebel or the revolutionary. I would describe this person as an unwilling subject, someone who disavows being ruled to such a degree that they are disposed to engage in disruptive and costly political resistance, if it stands a chance of bringing about regime change. Even if the revolutionary is able to find solidarity or community elsewhere (perhaps among rebel comrades), it is still prima facie bad that they disavow the supreme system of rule in their territory, the one that rules by force. I claim that this situation, one of unwilling subjection, is an objectively bad state of affairs for the individual, though it may be outweighed by other considerations.

The contrary case to the revolutionary is a willing subject, someone who freely assents to the system of rule in their territory. If I assent to rule, then I willingly accept my subjection as valid, all things considered. I believe that my subjection has a kind of point to it, because it corresponds to some value system that I can recognize, affirm, or endorse. In other words, I feel that my political order is acceptable or worthwhile, because it is organized according to some ideals or values that matter to the me. I may not affirm every aspect of my political order or be fully reconciled to it, but on some level, I accept its validity as a political order. I endorse, even if it is only minimally, the circumstances of my political subjection..$^{20}$

\subsection{Civic Alignment}

Weberian legitimacy represents the attainment of civic alignment, a situation in which political stability has been secured through widespread and sustained assent to rule among subjects. Assent to being ruled indicates a congruence between a regime's exercise of power and the attitudes of those subject to that power. It represents an alignment between what is claimed, and what is believed by subjects to be the case about the aims and functions of the political order. This sort of alignment means that the political order is supported by a shared sense that the value system(s) served by the ruling organization are acceptable and worthwhile. Since assent to rule requires that there be some value system through which the ruling organisation's use of violence makes sense, then when this assent is widespread, there is likely to be some nexus of values that most subjects can endorse as justifying the use of force. Even if the coherence of values is incomplete, it shows that the ends and aims of government are the object of broad support. This allows sub-

20 I have argued elsewhere that the intuitive contrast between willing and unwilling subjection marks out a morally significant ideal of voluntary rule, and that each person has a fundamental interest in attaining voluntary rule for themselves (Greene 2016, 82). 
jects to maintain an attachment and allegiance to the fundamental norms related to the exercise of power. This exerts, in turn, a form of pressure on the government to keep its exercise of power aligned with a value system, which in turn, keeps tyranny in check.

It is worth considering what happens in a political community when there is a lack of civic alignment. In Considerations on Representative Government, John Stuart Mill discusses a state that is made up of different identity groups:

\footnotetext{
"An altogether different set of leaders have the confidence of one part of the country and of another. The same books, newspapers, pamphlets, speeches, do not reach them. One section does not know what opinions, or what instigations, are circulating in another. The same incidents, the same acts, the same system of government, affect them in different ways; and each fears more injury to itself from the other nationalities, than from the common arbiter, the state." (Mill 1977, XIX, Part 2, 547)
}

Mill's analysis suggests that when the state is fragmented into multiple identity groups, then the normal process of public opinion formation breaks down. The different groups are exposed to different information about the actions of the government, along with different interpretations. These in turn translate into different perceptions by groups of subjects as to the validity of rule. For example, the very same action by the government (e.g. increasing the admission of immigrants) may strike some subjects as corresponding to the value system on the basis of which rule is considered valid. At the same time, it may strike others as not corresponding to a value system that they recognize, and thus like an abuse of power. To this latter group, it appears that the government's action corresponds to the value system of the opposing group, and so it can appear to advance the interests of a part rather than the whole. Insofar as rule is exercised according to the value system of one group, whose values are not shared by the other citizens, then the ruling organization can start to look like a form of tyranny to one group of subjects. This is the sense in which a lack of civic alignment is objectively bad.

Another philosopher who was concerned about civic alignment was Bernard Williams. Williams suggests that when a system of regulative beliefs in a society is sufficiently shared, it achieves something of value. While considering societies that are at a remove from our own, he says,

\footnotetext{
"We may see the members of this society as jointly caught up in a set of beliefs which regulate their lives and which are indeed unsound, but which are shared in ways that move the society further away from the paradigm of unjust coercion. In that case [...] we may be less eager to insist that its way of life [lacks legitimacy].” (Williams 2005, 71-72)
}

Thus he implies that in the absence of a shared set of beliefs about how to regulate their common life, any coercion that is exercised looks paradigmatically unjust- 
in fact, it looks like the unjust coercion that is characteristic of tyranny or foreign rule. Therefore, Williams argues that there is an important connection between having a shared system of regulative beliefs and avoiding the sort of unjust coercion that is characteristic of tyranny. To be clear, Williams isn't arguing that justice is realized whenever social order is based on a system of shared beliefs. Rather, he is saying that its absence is a step in the direction of injustice. The value of civic alignment only becomes clear when it is absent, because then the excessive use of violence and intimidation are required in order to manage social fragmentation and distrust.

The idea of civic alignment is distinct from mere political stability. It allows subjects to view their regime from a perspective that is oriented towards valuesas Gilley suggests, it allows citizens to 'relate to the powerful in moral terms'. Because there is willing deference to the guiding norms of the community, civic alignment brings a compulsory form of association closer to a voluntary form of association. It therefore allows a citizen's vertical and horizontal relations to approximate more closely the moral ideal of a voluntary association-a moral ideal that animates many approaches to democracy and liberalism, in fact. Therefore, it improves the vertical relationship between rulers and ruled, as well as the horizontal social relations among subjects. In this sense, it is good for me if I am subject to a system of political subjection in which my fellow citizens are willing subjects as well. Thus the value of civic alignment can be seen from the first-person perspective of a subject as well as the third-person perspective of an outsider viewing a political order.

\section{Weberian Legitimacy as a Normative Standard}

Having argued that Weberian legitimacy has moral significance, I now propose that we employ it as a normative standard of political legitimacy. The Weberian standard of political legitimacy that I advocate is the following: a state is legitimate to the degree that it is regarded by its subjects as having a valid claim to rule. That is to say, its subjects willingly accept the validity of the claim to rule made by those in the ruling organization, and they obey accordingly. The indicator for this standard would be, accordingly, the proportion of subjects that assent to rule. My support for this standard comes out of taking an evaluative approach to the question of political legitimacy. The aim of this approach is to define legitimacy in a way that (1) explains why it is valuable apart from other values such as justice, liberalism, and democracy, and (2) maintains alignment with the empirical study of legitimacy by social scientists. In this section I identify several reasons to adopt 
Weberian legitimacy as a normative standard for political legitimacy, addressing a few objections along the way.

\subsection{Universal Grounds for Criticism}

Other candidates for the normative standard of legitimacy face a problem of universalism. They are criticized because they employ standards of justice, democracy, and human rights that seem to be parochial. Whether or not this criticism is correct, it would be better to avoid it entirely. Weberian legitimacy is something that all states aim at, and so it serves as an undeniable basis for criticism. That is, no state can deny that it has failed in some respect when it fails to attain Weberian legitimacy. States that lack legitimacy can be criticized for lacking something that they themselves acknowledge as worth having, something they would agree that they should have. Insofar as any state would think it regrettable to lack Weberian legitimacy, and perhaps be ashamed to lack it, the standard has universal purchase. ${ }^{21}$ Aspiring states are especially concerned about their legitimacy, because they see that legitimacy is tied to their claim to be a state in the first place. ${ }^{22}$ Other standards for political legitimacy are more morally demanding because they require states to uphold liberty, democracy, and equality in order to be legitimate. Since those are not aims that all states must acknowledge insofar as they claim to be states, standards of legitimacy that rely on them are less solid grounds for universal criticism.

Furthermore, Weberian legitimacy better handles the imperialistic history of claims of justice. There is a sense that the West uses a historically- and culturallybound concept of political legitimacy to charge other states with legitimacy failures. At best, it is a practice of naive ethnocentrism to expect states outside the North American and European political traditions to embrace the standards for legitimate rule that have emerged from those traditions. At worst, it reads as selfserving rhetoric, aimed at shoring up economic domination through globalization. The attempts to avoid parochialism by cashing out legitimacy in terms of human rights hasn't worked. Human rights discourse is itself accused of being an

21 This idea is connected to Jonathan Lear's analysis of Socratic irony. He argues that Socrates repeatedly shows his interlocutors that they are failing to live up to the essential implicit standards of being a human being. The failure to live up to the ideal is a source of shame and internal dissonance (Lear 2011).

22 Studies of de facto states in post-conflict situations suggest that a goal high on their agenda is attaining Weberian legitimacy, as they perceive it as deeply tied to their existence as a state (Goddard 2006; Bakke et al. 2014; 2017). 
instrument of global hegemony, often with a sound historical basis. ${ }^{23}$ Thus Weberian legitimacy provides a basis for comparison that is far less tainted with neoimperialistic connotations.

This universalism means that there can be cross-national comparisons of legitimacy that are not inflected by 'Western' values in ways that invite to postcolonial critiques. When the measurement basis of legitimacy is perceived as neutral among states, it removes some grounds for states to object to its being investigated. Whereas some countries now exclude journalists and scholars that investigate human rights practices, they won't have the same grounds to exclude social scientists conducting research about political legitimacy. Moreover, this measurement neutrality allows for the links between legitimacy and liberal democracy to be demonstrated, rather than stipulated, since the connection isn't built into the definition of the metric of legitimacy.

\subsection{Aiming at Legitimacy}

The Weberian standard of political legitimacy better addresses a tension that troubles other accounts of legitimacy, namely, the tension between the group and the individual. It does so by treating legitimacy as a 'system-level property' that is nevertheless constituted by individual-level properties (Tyler 2006a). It is better to think of legitimacy as a system-level property when it comes to policy questions, and this is reflected in the current role that legitimacy judgments play in political deliberation..$^{24}$ For example, if a decision to support rebels in a civil war depends on whether the current regime is legitimate, then we are interested in a property of the regime, not a property that varies according to each individual subject. In fact, it is strange to say that a regime is legitimate for one subject and not for another-only highly individualistic accounts of voluntarism adhere to such a view (Simmons 2000). Other candidates for the normative standard of legitimacy take a system-level approach, but they do it through the imposition of a unanimous hypothetical perspective. The Weberian concept, on the other hand, allows for individual variation, thereby avoiding the pressure to collectivize through the imputation of unanimity. ${ }^{25}$ It therefore avoids idealizing away individual differ-

23 Samuel Moyn argues, for example, that the rise of human rights discourse in international affairs coincided with America's pursuit of a foreign policy of 'liberal internationalism', which was clearly to the economic advantage of the U.S. (Moyn 2010).

24 For a rich discussion of how our theorizing ought to be responsive to the functional role of legitimacy assessments, see chapter 5 of Buchanan 2013.

25 For further elaboration of this advantage, see Greene 2016, 91. 
ences, and it is able to incorporate historical sensitivity without becoming relativist or contextualist.

The ability to treat legitimacy as a system-level property without eliminating individual variation is also an advantage because it enables policy-makers to aim at legitimacy as an end in itself, without reducing it to a functional property. ${ }^{26}$ This is useful because in fact there may be tradeoffs between legitimacy and other social goods, and policy-makers need to be able to reckon with these tradeoffs. It allows them to treat the securing of legitimacy as one aim among others in a deliberation about what to do all things considered, whether it is a question of domestic health care reform or foreign military deployment. So the Weberian standard of legitimacy allows political actors to see legitimacy as a property of political orders in its own right, rather than treating legitimacy as a downstream byproduct of justice, or as an upstream determinant of whether to disobey or intervene in a regime.

\subsection{Is Weberian Legitimacy Moral Enough?}

A Weberian standard is able to show how achieving political legitimacy is valuable in a way that is distinct from the value of justice, liberalism, and democracy. Other normative approaches to political legitimacy have been accused of relying on liberal morality in various forms-ideals of autonomy, equality, freedom, and self-rule-and Weberian legitimacy cannot be accused of relying on these ideals. Weberian legitimacy avoids claims about justified or permissible coercion that are made in isolation from particular political circumstances, a criticism that is made of liberal theories of legitimacy (fairly, in my view). ${ }^{27}$ It also avoids relying on particular rights that must be guaranteed in order for a state to be legitimate.

Still, it might be thought that while the Weberian legitimacy I have described is a good-making feature of a state, it is too minimal, too morally thin. For example, there are a range of things we might consider relevant to legitimacy that aren't included in the standard. For example, what about a state that behaves immorally,

26 A functionalist account of legitimacy has been defended by Allen Buchanan, for example, although his views on legitimacy have evolved so much that I can't do them justice here. In his latest published work, he proposes that legitimacy is that property of institutions that allows for successful coordination on minimally justified institutions, i.e. the 'metacoordination view' (Buchanan 2013). In my view, this is too functionalist-it defines the criteria for the concept in terms of the signalling role that it plays in coordinating joint action, as seen from the outside.

27 Most theories of liberal legitimacy rely on objective moral claims about what constitutes permissible coercion. But any assumption about permissible coercion embeds a morality of coercion as such into the concept of legitimacy. This gets the explanatory order backwards, in my view. 
either to insiders or outsiders? The term 'external legitimacy' is often used to refer to the recognition of a state by those external to it, such as other states in the international community. In my view, external legitimacy is parasitic on the concept of internal legitimacy. We have an intuition that lacking internal recognition is a greater threat to a regime's legitimacy than lacking external recognition (Cozzaglio 2017). This reflects, correctly in my view, that the two audiences are not on a par. If a political order lacked subjects altogether, it would be impossible to make sense of it. So the primary audience consists of those persons without whom the entity's essential claim could not make sense-it would be not just difficult but impossible. This is to be contrasted with a secondary audience, those who take themselves to be related to the entity but whose existence is not strictly required in order to make sense of it. An example for a political order would be the international community', those outsiders whose recognition matters in various ways for its effective functioning. While outsiders are surely a kind of constituency for a regime, they are only secondary. That is because if you were to assume they didn't exist-i.e. a single-state world, with no external audience-then it would still be possible to make sense of the political order.

Therefore I am inclined to say that internal legitimacy is the core of the concept, and what we call external legitimacy matters only indirectly. However, this indirect relation might turn out to be very important. It might be that a new government within a state requires external resources and favor in order to govern effectively, and so external recognition becomes an essential precondition for securing internal legitimacy (Bakke et al. 2017).

But someone might be concerned with a different question, namely, whether a state ought to be regarded as legitimate if it is behaving immorally towards outsiders. For that matter, one may worry whether immoral treatment of insiders ought to disqualify a state as legitimate. These are valid concerns, but we have to be precise about what we mean by immoral treatment. In some sense of 'immoral treatment', states engage in this all the time, e.g. unjust taxation schemes, failure to pay reparations, exploitative trade deals with other nations, etc. If this compromised legitimacy, then no state would be legitimate. It seems better to retain other moral registers for these sorts of evaluations, such as whether a state is fair, egalitarian, or fully just. ${ }^{28}$ The standard of political legitimacy would have little point if it weren't distinct from other modes of evaluation, including individual morality. At any rate, when we see some practice as immoral, we would do well

28 There is still room for the recent proposal of Ronald Dworkin, who argues that the internal legitimacy of a state depends on its behaving morally in the international arena, because part of the state's claim of authority over its citizens depends on fulfilling its duty to uphold a system of international law (Dworkin 2013). 
to keep in mind the way in which our morality is shaped by culture and history. If female circumcision is deemed immoral, why isn't male circumcision?

Still, one might be worried that there are some levels of injustice that ought to be captured by any theory of legitimacy, such as systematic rights violations or minority oppression. It will be useful in this vein to compare the Weberian standard to the Lockean standard, as Locke was concerned about dissident minorities being able to protest rights violations. According to Locke, civil government is legitimate when it attains the tacit consent of its subjects and governs in such a way as to protect natural rights (Simmons 1999). Thus, Locke famously argues that when a government systematically abuses its power, it may be resisted with force (Locke 1980, 105-124). Locke also argues that one cannot consent to immoral arrangements, such as slavery or tyranny. Therefore, someone might think that what I have proposed is similar to Lockean tacit consent but less appealing overall, because at least Locke addresses resistance to tyranny and protection of rights.

What a Weberian view captures, that is left out of the Lockean view, is that what is affirmed and assented to in terms of a political order comes apart from whether the political order is worthy of that assent. Neither of these can be conceptually reduced to the other. It cannot be maintained that a regime is not truly just unless it is assented to, because regimes can deliver justice in the absence of assent (e.g. an unwelcome peace-keeping authority, or a national guard sent in to enforce racial segregation). Conversely, one should not say that a regime is not truly assented to unless it's just, because you can have assent to bad regimes. Therefore, the Weberian conception deliberately keeps open the possibility that there may be genuine assent to rule that does not correspond to just or rightsrespecting rule, and vice versa.

What is lost in the absence of legitimacy, as I have defined it, is not the same thing as a lack of justice or a lack of rights. Locke himself admits that it is a distinct shortcoming of government if it loses the support of the people. He says, "When the governors have brought it to this pass, to be generally suspected of their people, [...] [this is] the most dangerous state which they can possibly put themselves in; wherein they are the less to be pitied, because it is so easy to be avoided [...] if he really means the good of his people, and the preservation of them." (Locke 1980, 106) Thus, even Locke acknowledges that Weber is on to something.

In order for political legitimacy to remain a distinct mode of evaluation that corresponds to a distinct moral defect in a state, it cannot include all the good things that we might hope for politically, such as rights, equality, and democracy. Now, I am not saying that violating rights or oppressing minorities aren't important for the moral evaluation of states. But we have standards of moral evaluation for those things: liberalism, equality, justice. What the Weberian concept of legitimacy can show, instead, is how those things can come apart from polit- 
ical legitimacy-that is to say, a society may make progress towards justice but lose out on legitimacy along the way (for example, arguably, the EU in the last decade). Thus the fact that Weberian legitimacy corresponds to something unique and distinct counts in favor of using it as a normative standard. Only when it is definitionally independent can it reveal what is at stake when we are faced with making tradeoffs between multiple political values.

I have been arguing that 'stable civic alignment' has moral value, but I want to clarify that its value is not unconditional. In my view, legitimacy is an instance of dependent non-instrumental value, because its value cannot be reduced to other values, but it nevertheless may be conditional on them (Sandbu 2007). In fact, political ideals such as equality, democracy, solidarity all work like this. For instance, the ideal of equality does not have unconditional moral value; nevertheless, it is something to be aimed at as more than just a means to an end. I say that legitimacy has non-instrumental value because it is important enough to be its own aim, an end pursued by rulers and citizens alike, not merely as a means to justice.

Someone inclined to be idealistic about legitimacy might still doubt the value of Weberian legitimacy, maintaining that it could only have moral significance in those political orders that also achieve justice. But this is too demanding as a mere value claim. An analogy would be to maintain that it is only good for a person to love someone who is always honest with them. It is probably better for someone to love an honest person, but that doesn't mean it can't be good for them to love someone who bends the truth. In other words, normally a life without love is worse than one with love, even in the absence of perfect honesty. One would have to define love in terms of honesty in order to uphold such a demanding view about the value of love. As honesty and love are two distinct values in a human life, so justice and legitimacy are two distinct values in a political community. Legitimacy is worth preserving for its own sake, just as it is worth preserving love even when there has been a lapse in honesty.

\section{Conclusion}

Weberian legitimacy corresponds to something morally substantive-something that we care about and are right to care about. The value of civic alignment can hold its own against other competing standards of legitimacy that rely on liberal ideals of equality and rights. What Weberian legitimacy lacks in idealism, it makes up for in its ability to provide a universally-acknowledged basis for critique. Thus Weberian legitimacy provides a measurable basis for the moral eval- 
uation of states while avoiding the most controversial assumptions about liberal individualism, equality, and democracy-ideals that are viewed with suspicion by many, for good historical reasons. At the same time, it can show why legitimacy is distinctive and valuable, apart from other ways we might morally evaluate states. Therefore Weberian legitimacy deserves consideration as a normative standard of political legitimacy.

Acknowledgment: For helpful comments, I would like to thank the journal editors and an anonymous referee. For helpful discussion, I would like to thank Joshua Cohen, Ilaria Cozzaglio, David Estlund, Aziz Huq, Steven Klein, Eric Miller, David Owens, Joseph Raz, Robert M. Simpson, and Allen Wood.

\section{References}

Alkire, S. (2005), Why the Capability Approach?, in: Journal of Human Development 6, 115-135 -/J. Foster (2011), Counting and Multidimensional Poverty Measurement, in: Journal of Public Economics 95, 476-487

Arendt, H. (1969), Reflections on Violence, New York Review of Books, February 27

- (1993), What Is Authority?, in: Between Past and Future, New York, 91-141

Aristotle (1984), The Complete Works of Aristotle. Vol. 1 \& 2, ed. J. Barnes, Princeton

Bakke, K. M./A. M. Linke/J. O'Loughlin/G. Toal (forthcoming), Dynamics of State-Building after War: External-Internal Relations in Eurasian de Facto States, in: Political Geography 61

-/J. O’Loughlin/G. Toal/M. D. Ward (2014), Convincing State-Builders? Disaggregating Internal Legitimacy in Abkhazia, in: International Studies Quarterly 58, 591-607

Beetham, D. (1985), Max Weber and the Theory of Modern Politics, New York

- (1989), Max Weber and the Liberal Political Tradition, in: European Journal of Sociology /

Archives Européennes de Sociologie 30, 311-323

- (1991a), Max Weber and the Legitimacy of the Modern State, in: Analyse \& Kritik 13, 34-45

- (1991b), The Legitimation of Power, London

- (2013), The Legitimation of Power, London

Buchanan, A. (2013), The Heart of Human Rights, Oxford

-/R. O'Keohane (2006), The Legitimacy of Global Governance Institutions, in: Ethics \& International Affairs 20, 405-437

Copp, D. (1999), The Idea of a Legitimate State, in: Philosophy \& Public Affairs 28, 3-45

Cozzaglio, I. (2017), Beliefs in Legitimacy and the Normative Role of Coherence, University of Warwick, Graduate Conference in Political and Legal Theory, February 18

Derman, J. (2013), Max Weber in Politics and Social Thought: From Charisma to Canonization, Cambridge-New York

Dworkin, R. (2013), A New Philosophy for International Law, in: Philosophy \& Public Affairs 41, 2-30

Estlund, D. (2007), Democratic Authority: A Philosophical Framework, Princeton

- (2014), Utopophobia, in: Philosophy \& Public Affairs 42, 113-134 
Fearon, J. D. (2003), Ethnic and Cultural Diversity by Country, in: Journal of Economic Growth 8, 195-222

Geuss, R. (2008), Philosophy and Real Politics, Princeton

Gilbert, M. (2006), A Theory of Political Obligation: Membership, Commitment, and the Bonds of Society, Oxford

Gilley, B. (2006a), The Meaning and Measure of State Legitimacy: Results for 72 Countries, in: European Journal of Political Research 45, 499-525

- (2006b), The Determinants of State Legitimacy: Results for 72 Countries, in: International Political Science Review 27, 47-71

- (2008), Legitimacy and Institutional Change: The Case of China, in: Comparative Political Studies 41, 259-284

- (2009), The Right to Rule: How States Win and Lose Legitimacy, New York

- (2012), State Legitimacy: An Updated Dataset for 52 Countries, in: European Journal of Political Research 51, 693-699

Goddard, S. E. (2006), Uncommon Ground: Indivisible Territory and the Politics of Legitimacy, in: International Organization 60, 35-68

Green, L. (1990), The Authority of the State, London

Greene, A. (2016), Consent and Political Legitimacy, in: Sobel, D./P. Vallentyne/S. Wall (eds.), Oxford Studies in Political Philosophy 2, 71-97

- (2017), The Promise of Political Realism, SSRN Scholarly Paper ID 3043529, Rochester, Social Science Research Network, URL: https://papers.ssrn.com/abstract $=3043529$

-/I. Cozzaglio (2017), Can Power Be Self-Legitimating? Williams's Critique of Hobbes and Weber on Political Legitimacy, SSRN Scholarly Paper ID 3040406, Rochester, Social Science Research Network, URL: https://papers.ssrn.com/abstract=3040406

Habermas, J. (1996), Between Facts and Norms: Contributions to a Discourse Theory of Law and Democracy, Cambridge/MA

Hobbes, T. (1998), Hobbes: On the Citizen, ed. Tuck, R./M. Silverthorne, Cambridge

Jackson, J./A. Z. Huq/B. Bradford/T. R. Tyler (2013), Monopolizing Force? Police Legitimacy and Public Attitudes Toward the Acceptability of Violence, in: Psychology, Public Policy, and Law 19, 479-497

Kalyvas, A. (2008), Democracy and the Politics of the Extraordinary: Max Weber, Carl Schmitt, and Hannah Arendt, Cambridge

Klein, S. (2017), Between Charisma and Domination: On Max Weber's Critique of Democracy, in: The Journal of Politics 79, 179-292

Klosko, G. (2005), Political Obligations, Oxford

Lassman, P. (2000), The Rule of Man over Man: Politics, Power, and Legitimation, in: Turner, S. (ed.), The Cambridge Companion to Weber, Cambridge, 83-98

Lear, J. (2011), A Case for Irony, Cambridge/MA

Levi, M./A. Sacks/T. R. Tyler (2009), Conceptualizing Legitimacy, Measuring Legitimating Beliefs, in: American Behavioral Scientist 53, 354-375

Locke, J. (1980), Second Treatise of Government, ed. C. B. Macpherson, Indianapolis

Mill, J. S. (1977), The Collected Works of John Stuart Mill, ed. J. M. Robson, Vol. XIX, Part 2, Toronto

Moyn, S. (2010), The Last Utopia: Human Rights in History, Cambridge/MA

Peter, F. (2009), Democratic Legitimacy, New York

- (2016), Political Legitimacy, in: The Stanford Encyclopedia of Philosophy, Edward N. Zalta (ed.), URL=https://plato.stanford.edu/archives/sum2017/entries/legitimacy 
Pettit, P. (2012), On the People's Terms: A Republican Theory and Model of Democracy, Cambridge

Rawls, J. (1971), A Theory of Justice, Cambridge/MA

- (2001), Justice as Fairness: A Restatement, ed. Erin Kelly, Cambridge/MA

Raz, J. (1986), The Morality of Freedom, Oxford

- (2006), The Problem of Authority: Revisiting the Service Conception, in: Minnesota Law Review 90, 1003-1044

Rossi, E./M. Sleat (2014), Realism in Normative Political Theory, in: Philosophy Compass 9, 689-701

Sandbu, M. E. (2007), Valuing Processes, in: Economics and Philosophy 23, 205-235

Scharpf, F. W. (1999), Governing in Europe: Effective and Democratic?, Oxford

Schmidt, V. A. (2013), Democracy and Legitimacy in the European Union Revisited: Input, Output and 'Throughput', in: Political Studies 61, 2-22

Sen, A. (1999), Development as Freedom, Oxford

Shaw, T. (2008), Max Weber on Democracy: Can the People Have Political Power in Modern States?, in: Constellations 15, 33-45

Simmons, A. J. (1999), Political Consent, in: Morris, C. W. (ed.), The Social Contract Theorists: Critical Essays on Hobbes, Locke, and Rousseau, Lanham, 121-141

- (2000), Justification and Legitimacy: Essays on Rights and Obligations, Cambridge

- (2010), Ideal and Nonideal Theory, in: Philosophy \& Public Affairs 38, 5-36

Sunshine, J./T. R. Tyler (2003), The Role of Procedural Justice and Legitimacy in Shaping Public Support for Policing, in: Law \& Society Review 37, 513-548

Tasioulas, J. (2010), The Legitimacy of International Law, in: Besson, S./J. Tasioulas (eds.), The Philosophy of International Law, Oxford, 97-116

Tyler, T. R. (2006a), Psychological Perspectives on Legitimacy and Legitimation, in: Annua. Review of Psychology 57, 375-400

- (2006b), Why People Obey the Law, Princeton

-/J. Jackson (2013), Future Challenges in the Study of Legitimacy and Criminal Justice, SSRN Scholarly Paper ID 2141322, Rochester, Social Science Research Network, URL: https://papers.ssrn.com/abstract $=2141322$

Weber, M. (1978), Economy and Society: An Outline of Interpretive Sociology, Berkeley

Weigand, F. (2017), Afghanistan's Taliban-Legitimate Jihadists or Coercive Extremists?, in: Journal of Intervention and Statebuilding 11, 359-381

Williams, B. (2005), In the Beginning Was the Deed: Realism and Moralism in Political Argument, ed. Geoffrey Hawthorn, Princeton

Wolin, S. S. (1981), Max Weber: Legitimation, Method, and the Politics of Theory, in: Political Theory $9,401-424$ 
Brought to you by | UCL - University College London 